\title{
SIGNIFICANCE OF VITAMIN D3 IN ALLERGIC REACTIONS AND IGE LEVELS IN ASTHMIC PATIENTS.
}

\footnotetext{
1. M.Sc, M.Phil

Ex-Lecturer Physiology

Baqai Medical University Karachi

2. MBBS, M.Phil

Associate Professor Biochemistry

Sir Syed College of Medical

Sciences (for girls), Karachi.

3. MBBS, M.Phil

Assistant Professor Physiology

Baqai Medical University Karachi.

4. MBBS, M.Phil

Assistant Professor Anatomy

Baqai Medical University Karachi.

5. MBBS, M.Phil

Associate Professor Physiology

Chandka Medical College Larkano.

6. M.Sc, M.Phil

Assistant Professor Physiology

Baqai Medical University Karachi.
}

Correspondence Address:

Dr. Ruqaya

Department of Physiology

Baqai Medical University Karachi

ruqnanrs2009@yahoo.com

Article received on:

29/04/2019

Accepted for publication:

$15 / 08 / 2019$
Hira Liaquat ${ }^{1}$, Jai Parkash Panjwani², Syed Adnan Ahmed ${ }^{3}$, Tayyaba Kazmi ${ }^{4}$, Amar Lal Dodani $^{5}$, Ruqaya $^{6}$

ABSTRACT... Objectives: When a person is exposed to the sun, vitamin D3 is a nutrient produced by the body. Unless we don't get enough sunlight, we can't get enough vitamin D3. In the case of asthma, the respiratory tract expands due to mucus because they become inflamed. Inflammation is the body's reaction to injury, infection or irritation. Researchers are interested in vitamin D3 because it can decrease inflammation, theoretically it can make the airway recovered. The study aims to analyze the significance of Cholecalciferol (Vitamin D3) in asthmatic cases. Study Design: Comparative study. Setting: Baqai Medical University's allied Hospitals. Period: From July 2014 to April 2015. Material \& Methods: The study included diagnosed asthmatic individuals. IgE and Vitamin $D_{3}$ levels were performed by ELISA kit method. Result: A comparative study was performed between the 50 healthy subjects and 50 Asthmatic patients. Mean \pm SD was calculated for Vitamin D3 level and IgE of cases (asthmatic patients) and control (healthy subjects). It was found that vitamin D3 level was significantly low in asthmatic patients $(11.53 \pm 4.11)$ as compared to healthy subjects $(25.32 \pm 4.79)$, with statically significant difference as shown by the $\mathrm{p}$-value $<0.01$. Correspondingly mean value of IgE value was higher in asthmatic cases $(4.01 \pm 0.65)$ in our study in comparison with healthy subjects $(3.12 \pm 0.43)$ with statically significant difference ( $p$-value $<0.01)$. Conclusion: The present study signifies Vitamin $D_{3}$ functions in immune system and inflammatory reactions. Vitamin $D$ enhances immune cells function thereby reduces inflammatory responses. Immunoglobulin E level in serum was higher in asthmatics as compared to normal subjects.

Key words: Asthma, IgE Vitamin $\mathrm{D}_{3}$ Allergic reaction.

Article Citation: Liaquat H, Panjwani JP, Ahmed SA, Kazmi T, Dodani AL, Ruqaya. Significance of Vitamin $D_{3}$ in allergic reactions and IgE levels in asthmic patients. Professional Med J 2020; 27(3):563-569.

DOI: 10.29309/TPMJ/2020.27.3.3657

\section{INTRODUCTION}

Immunoglobulin $\mathrm{E}(\mathrm{IgE})$ is an important component of allergic reactions. When an antigen binds to the receptor for $\lg E$ a series of events starts with generation of large amount of body fluids. This brings the blocking of smooth muscles in the lungs which ultimately results in the obstruction of air passage in the lungs. ${ }^{1}$ It was proven earlier that reduction in immunoglobulin $E$ results in the reduction of $\lg E$ receptors on Basophils. ${ }^{2}$ According to the study by MacGlashan and Colleague, a treatment of omalizumabto the patients of rhinitis for three months effectively decreased the receptors for IgE by many folds i.e. from 2,22,000 to $8000 .^{3}$ Another study demonstrated the reduction in free IgE level and it's receptor for alpha subunit by the treatment of the same drug (omalizumab). This study selected patients that had occasionally susceptible rhinitis to ragweed. It was revealed by this study that free IgE levels were reduced by $96 \%$ while receptors for alpha subunit of IgE were down-regulated by $70 \%$ after three days treatment with omalizumab. ${ }^{4}$

Patients with Atopic asthma without progressive allergic reaction and non-atopic asthma do not produce excessive receptors for IgE rather they have large expression of $\gamma$-chain of IgE receptors. So the level of the bound IgE on dendritic cells is almost same in these patients as it is on basophils in progressive atopic asthma patients. ${ }^{5}$ Whether non-atopic asthma patients can up-regulate the surface resolution of IgE receptor (FcERI), remain ambiguous in disease scenes in nearby inflammatory sites. Unfavorable susceptibility to dendritic cells in nearby destinations remains 
a series of dynamic tests. The natural defense mechanism of the body (dendritic cells) in intestine, nose, lungs and skin has the ability to protect the body from environmental allergens. Omalizumab drug increases dendritic cells in subjects with conventional allergic rhinitis. ${ }^{6}$

\section{Correlation of vitamin D and asthma}

Asthma is a chronic disorder associated with immunological inflammation and is prevalent worldwide now a day. For the management of asthma different pharmacological treatments are available. There is an aggregate suggestions that Vitamin D insufficiency has a vital impact on asthma progression. Some studies were against this hypothesis. ${ }^{7}$

\section{Presence of vitamin D3 in airway epithelium}

Previously it was studied that like many other tissues, airway epithelial cells also expresses 1- hydroxylase enzyme. This enzyme converts the inactive form of vitamin D3 to its active form. Epithelial cells of lungs have high amount of this enzyme shows the presence of high amount of active form of vitamin D3. ${ }^{8}$

\section{Vitamin D3 in the smooth muscles of the bronchi}

It has been apparent from previous studies that vitamins are a significant portion of bronchial smooth muscle cells in airway remodelling. Bosse et al. analysed whether vitamin $D$ receptor (VDR) is available in lumen narrowing, and bronchoconstriction. It is revealed that VDR are present in bronchial smooth muscle at transcriptional and translational level. This evidence is weighted by increasing 24-hydroxylase enzyme.24hydroxylase regulates the homeostasis of vitamin $\mathrm{D}$ by triggering the breakdown of vitamin $\mathrm{D} .{ }^{9}$ There was 200 -fold change in the receptors of vitamin $D$ after this methodology. It was shown by a study in the past that bronchial smooth muscles produce higher quantity of 24-hydroxylase enzyme. Furthermore it was demonstrated that calcitriol inhibits DNA synthesis in bronchial muscles after induction of particular dose i.e. $100 \mathrm{nM}$ calcitriol. ${ }^{10}$

Previous study indicated that lower vitamin D levels can lead to bronchial smooth muscle production and cytokine release leading to airway redesign. In another study the microarray technology and PCR was used to observe gene expression after 1,25(OH)2D3 stimulation. The gene expression of Prostaglandins enhances by Vitamin $D$ and the combination of certain prostaglandin is also done by this vitamin. ${ }^{11}$

\section{Vitamin D3 and vascular smooth muscle}

In one of the study it was evaluated that $1,25(\mathrm{OH}) \mathrm{D} 3$ affect the formation of new blood vessel in smooth muscle. The study revealed that $1,25(\mathrm{OH}) 2 \mathrm{D} 3$ depends to a large extent on its added environment. In non-resting cells, $1,25(\mathrm{OH}) 2 \mathrm{D} 3$ attenuates the growth response of thrombin, certain growth factors, and thrombin induces c-myc RNA. Contradictory, in dormant cells, vitamin $D$ stimulate the synthesis of thrombin. ${ }^{12}$

\section{Immunomodulatory effects of vitamin}

Vitamin D also has its impact on immune system. Vitamin $D$ receptors are present on monocytes and lymphocytes. ${ }^{13}$ Vitamin D and asthmarelated immune cell interactions have significant immunomodulatory effects. Cross-linking of the high affinity IgE receptor $\mathrm{FcRI}$ by antigen binding to the IgE antibody provides a major immune potentiating effect on polar cell initiation. ${ }^{14}$ Rod cells appear to be expanding in the air route and sound control of asthma patients. It was studied that 1,25(OH)2D3 increases the control and capacity control of polar cells. It was found that $1,25(\mathrm{OH}) 2 \mathrm{D} 3$ promotes cell breakdown and prevents polar cell precursors development in mouse bone marrow. At different stages of polar cell improvement, there is also a dose-dependent limitation of $1,25(\mathrm{OH}) 2 \mathrm{D} 3$ pole cell separation. This gives the impression that vitamin $D$ receptor (VDR) has important regulatory function in polar cell differentiation and development. The polar cell precursors obtained from mice removed from VDR experienced accelerated development in vitro and provided higher responsive rod cells than wild type mice. ${ }^{15}$ Previously, it was studied vitamin $\mathrm{D}$ may play an important inhibitory role in the differentiation, maturation and homing of mast cells into allergic airways. This hypothesis is confirmed by the experimentation on mice. It 
was revealed that VDR-deficient mice had less polar cells in skin as compared to wild type mice. Vitamin D inhibits the synthesis of $\mathrm{TH} 1$ cytokine IFN. ${ }^{16}$

\section{MATERIAL AND METHOD}

\section{Study Protocol}

The comparative study was conducted at the Department of Physiology, Baqai Medical University of Karachi, from July 2014 to April 2015. The patients were from allied hospitals of Baqai (Fatima and BIDE) and the Jinnah Post Graduate Medical Centre. This study was conducted after approval by the Ethics Committee of the Baqai Medical University.

Asthmatic patients included 50 men and women, with an average age of 40-79 years and 30-71 years, respectively. For comparison 50 individuals without asthma as normal subjects, male and female with average ages of 30-62 and 25-56 years were included in the study.

\section{Estimation of Immunoglobilin E (IgE)}

The estimation of IgEwas done by ELISA. ${ }^{17}$ The mechanism is based on the binding of $\operatorname{IgE}$ monoclonal antibody with the $\lg E$ present in our sample. The sample was added to an IgE monoclonal antibody restrained on a polystyrene microtiter well and incubated with a dissociation buffer. The lgE present in the sample will also bind to the antibody. ${ }^{18}$ Horseradish peroxidase was used as a binding reagent. The remaining sample was removed after wash. The IgE molecule is pack in between the solid phase and the enzymelinked antibody because the conjugate reagent binds immunologically to $\operatorname{lgE}$ on the well. ${ }^{19}$ The microtiter plates were washed after being incubated at room temperature. Water was used for washing. All the unbound antibodies were removed after washing. ${ }^{20} \mathrm{~A}$ blue color compound is obtained after addition of Tetramethylbenzidine (TMB) solution. Incubation of 20 minutes was required for the development of color. ${ }^{21}$ Stop reagent stopped the development of color after certain time. Resultant color compound was measured by spectrophotometer at suitable wavelength. The intensity of the color indicates the concentration of measured compound i.e. $\operatorname{lgE} .^{22}$ This process is accurate for the estimation of immunoglobulin E. ${ }^{23}$

\section{Estimation of vitamin D}

For the quantitative measurement of $25(\mathrm{OH})$ Vitamin D3 and 25(OH) VitaminD2, ELISA was performed. It is an enzyme-linked immunosorbentassay. ${ }^{24}$ The dissociation buffer was added to the wells coated with the specific antibody. Standards and samples were then added to the wells and allowed to dissociate $25(\mathrm{OH})$ vitamin $\mathrm{D}$ from the vitamin $\mathrm{D}$ binding protein. After incubation of 2 hours at room temperature, the antibody binds $25(\mathrm{OH})$ vitamin $\mathrm{D}$ from the sample in a competitive manner in the presence horseradish peroxidase (HRP) and itself captured by the specific monoclonal antibody. ${ }^{25}$ The plate is then washed to leave a complex with bound $25(\mathrm{OH})$ vitamin $D$ from the sample. The stop solution was added to stop the substrate reaction and the resulting yellow color was read at $405 \mathrm{~nm} .^{26}$

\section{Calculation}

Vitamin D and $\lg E$ present in the sample were calculated by using following formula:

$\mathrm{B} / \mathrm{BO}(\%)=\mathrm{OD}($ Calibrator, Controlorsample $) \times 100$

\section{OD (Zero Calibrator)}

\section{Analysis of Data}

Version 19.0 of SPSS was used for data analysis. A categorical variable like gender was represented by frequency and percentage, while patient spirometry values and age (numerical variables) were represented by Mean \pm Standard deviation. To analyze the significance of theses variables on level of vitamin D and IgE level, linear regression analysis was done. $\mathrm{P}$ value $<0.01$ was considered statistically significant.

\section{RESULTS}

The study included a total of 100 individuals. Of these, 50 patients diagnosed with control asthma were reassessed as asthmatic and 50 patients served as matched controls. According to the results, the proportion of males and females in 
asthma patients was similar, irrespective of gender ( $p$ value 0.584 ). In asthma cases, the mean age was $49.4 \pm 12.8$, compared with $40.6 \pm 10.1$ in the control group, and the mean age difference between the case and the control group was significant ( $p$ value $<0.01$ )

An average comparison of vitamin D3 levels and $\operatorname{lgE}$ between cases and controls is shown in Table-l. It was revealed that vitamin D3 level was approximately half in patients of asthma (11.53 \pm 4.11) than those without asthma (25.32 \pm 4.79$)$. Conventionally IgE value was significantly higher in Asthmatic patients (4.01 \pm 0.65$)$ in comparison with non-asthmatic (3.12 \pm 0.43$)$. The difference in Vitamin D and IgE level was statistically significant between these two groups.

In addition, in order to observe the relationship between vitamin D3 and the severity of asthma patients, vitamin D3 levels were classified according to severity. We found that in asthma cases, 51(95\%) patients were severely deficient and only 3 (7\%) patients found mild and adequate vitamin D3 levels. In the control group, $52(86 \%)$ individuals were found to have mild and adequate levels of vitamin D3, and 11 (19\%) individuals were severely deficient in vitamin D3 levels. The association between vitamin D3 levels and asthma was statistically significant ( $p$-value $<0.01)$.

Figure-1. Correlation of Vitamin D3 and IgE in patients

Correlations were analysed between vitamins $\mathrm{D}_{3}$ and IgE in Patients. $\mathrm{R}^{2}$ value was 0.002 , which shows $2 \%$ variation, which was explained as strong correlation between Vitamin $\mathrm{D}_{3}$ and IgE.

\section{Figure-II. Correlation of Vitamin D3 and FVC in patients}

Correlations were analysed between vitamins $D_{3} F V C$ in Patients. $R^{2}$ value was 0.0035 , which shows $0.35 \%$ variation, which was explained as strong correlation between Vitamin $\mathrm{D}_{3}$ and FVC.

\begin{tabular}{|l|c|c|c|}
\hline \multicolumn{1}{|c|}{ Variables } & Patients & Healthy Subjects & P-Value* \\
\hline & Mean \pm SD & Mean \pm SD & $<0.01$ \\
\hline Vitamin D3 level $(\mathrm{ng} / \mathrm{ml})$ & $11.53 \pm 4.11$ & $25.32 \pm 4.79$ & $<0.01$ \\
\hline IgE & $4.01 \pm 0.65$ & $3.12 \pm 0.43$ & \\
\hline${ }^{*}$ p-value calculated by Independent t-test & \\
\hline
\end{tabular}

\begin{tabular}{|l|c|c|c|}
\hline \multicolumn{1}{|c|}{ Variables } & Patients & Healthy Subjects & P-Value* $^{*}$ \\
\hline & $\mathbf{n ~ ( \% )}$ & $\mathbf{n}(\%)$ & \\
\hline Vitamin D3 level $(\mathbf{n g} / \mathbf{m l})$ & & & $<0.01$ \\
\hline Severe deficiency $(\leq 18 \mathrm{ng} / \mathrm{ml})$ & $51(95 \%)$ & $11(19 \%)$ & \\
\hline Mild/Sufficient $(>18 \mathrm{ng} / \mathrm{ml})$ & $03(07 \%)$ & $52(86 \%)$ & \\
\hline *P-value calculate by using Chi-square analysis & & \\
\hline
\end{tabular}

Table-II. Severity condition of Vitamin D3 among patients and healthy subjects

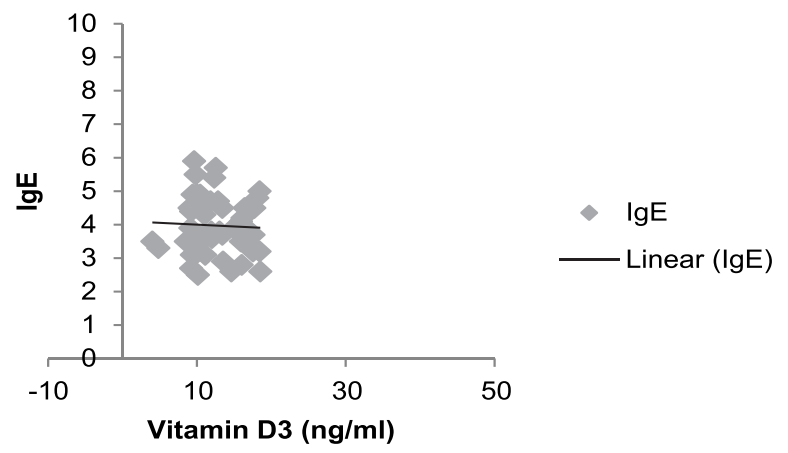

Figure-1. Graphical presentation of correlation of Vitamin D3 and IgE in patients.

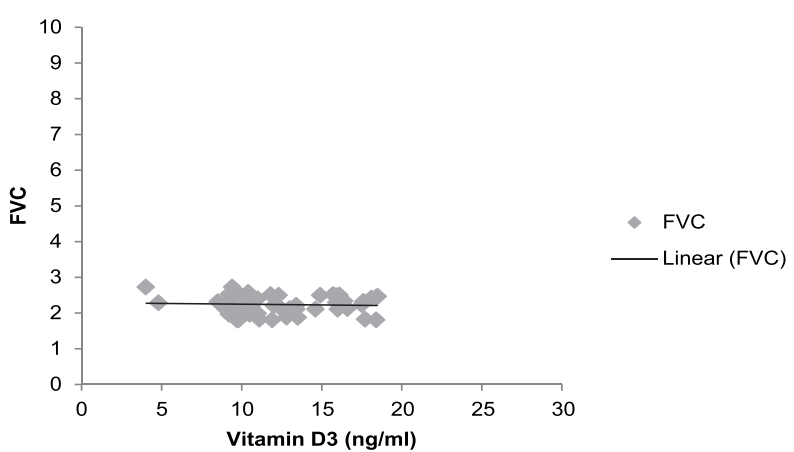

Figure-II. Graphical presentation correlation of Vitamin D3 and FVC in patients. 


\section{DISCUSSION}

Asthma has been recognized as a disease that causes an increase in morbidity and mortality. Despite several epidemiological studies around the world, the severity of the asthma problem has not been determined. In fact, the lack of consistency in studies on the prevalence of asthma may be due to unclear diagnostic criteria, non-standardized research protocols, different approaches, environmental acquaintances, and healthcare setup. There is a positive correlation between asthma and age. This study shows that there are more asthma patients in the 29-85 age group. Asthma is age-related; with age, the number of patients with asthma will be higher than normal. ${ }^{27}$ Our research supports previous research, which is similar to the results of Svedahl $S$ et al. ${ }^{28}$

The homeostasis of immune system is dependent on Vitamin D3 to some extend in particular the inborn immunity. It directly induces expression of the cathelicid in gene. Vitamin D aids in the synthesis of $T$ immune cells. It may include the up regulation of expression of IL-10 and TGF $\beta$, the inhibitory cytokines and may also involve in CD4-positive T lymphocytes growth regulation. In steroid resistant asthma vitamin D may opposes the resistance of glucocorticoids. According to previous researches vitamin D3 insufficiency exaggerate the possibility of lung diseases, and can cause use gasping in children and adults. This may results in acute asthma attacks. Previous studies signify the importance of vitamin $D$ as it is involve in neonatal lungs growth and its functions. These researches correlate the vitamin D deficiency with asthma and its severity. ${ }^{29}$ Our research is based on the comparative study of vitamin $\mathrm{D}$ level in patients of asthma with healthy individuals. Our results demonstrated the higher levels of vitamin $D$ in healthy subjects than asthma patients. In a linear model, a negative relationship between serum vitamin D3 levels and asthma was found. Moreover, after controlling age and gender, this relationship increased as compared to linear analysis. The results of this study suggests that vitamin $D$ is lower in patients of asthma. Our results are consistent with other studies, indicating a decrease in vitamin D3 levels in adults and asthmatic children. ${ }^{30}$ Although some of these authors have found that vitamin D3 deficiency is only associated with severe asthma exacerbations. ${ }^{31}$ Conversely, the results presented by other scientists are contrary, indicating that there is no significant correlation between low vitamin D3 status and asthma incidence. ${ }^{32}$ Some studies are contrary to our hypothesis rather it was suggested that higher vitamin $D$ have no impact on asthma of IgE level. ${ }^{33}$ With insufficient levels of vitamin $\mathrm{D}$, there is a risk of severe exacerbations in children. Although no association was found between vitamin D3 and bronchiectasis or airway hyper responsiveness. This study does not confirm the association of vitamin D with severity or complications of asthma. Other factors may also affect this relationship. One possibility may be the less exposure of sunlight to the subjects with asthma as they may spend more time indoors. Vitamin D3 deficiency is common in areas of the world that are full of sunlight. Ethnicity, impaired production of vitamin $\mathrm{D}$ and usage of certain sunscreens creams are the other factors that may contribute to the lower level of this vitamin.

\section{CONCLUSION}

This study revealed that vitamin $D$ is involved in proper functioning of lungs. Intervention studies are currently needed for asthma patients with low serum vitamin D3 in order to reveal the association of vitamin D with asthma. Asthmatics have higher serum IgE levels than normal subjects. It is thought that higher IgE levels increase as the severity of asthma. In addition asthma patients are severely deficient of vitamin $D$ than controls. Therefore, it is concluded that the level of IgE may contribute in the severity of asthma, Vitamin D also play a vital role to reduce the effects produced in asthmatic situation.

\section{ACKNOWLEDGE}

We are highly thankful to Prof. Dr. Sikandar Ali Sheikh for his consistent guidance and support during writing this project.

Copyright $\odot 15$ Aug, 2019. 


\section{REFERENCES}

1. Howarth, P. H., Durham, S. R., Kay, A. B., \& Holgate, $\mathrm{S}$. T. The relationship between mast cell-mediator release and bronchial reactivity in allergic asthma. $J$ Allergy Clin Immunol. 1987; 80:703-711.

2. MacGlashan, D., Xia, H. -Z., Schwartz, L. B., \& Gong, J. IgE-regulated loss, not IgE-regulated synthesis, controls expression of FceRI in human basophils. $J$ Leukoc Biol. 2001; 70: 207-218.

3. MacGlashan, D., Xia, H. -Z., Schwartz, L. B., \& Gong, $\mathrm{J}$. IgE-regulated loss, not IgE-regulated synthesis, controls expression of FceRI in human basophils. $J$ Leukoc Biol. 2001; 70:207-218.

4. Lin, H., Boesel, K. M., Griffith, D. T., Prussin, C., Foster, B., Romero, F. A., et al. Omalizumab rapidly decreases nasal allergic response and FceRI on basophils. $J$ Allergy Clin Immunol. 2004; 113:297-302.

5. Litonjua AA, Hollis BW, Schuemann BK, Celedón JC, Fuhlbrigge AL, Raby BA, Weiss ST. Low serum vitamin D levels are associated with increased asthma exacerbations among children using regular inhaled corticosteroids. J Allergy Clin Immunol. 2008; 121:S144.

6. Litonjua AA, Hollis BW, Schuemann BK, Celedón JC, Fuhlbrigge AL, Raby BA, Weiss ST. Low serum vitamin $D$ levels are associated with increased asthma exacerbations among children using regular inhaled corticosteroids. J Allergy Clin Immunol. 2008; 121:S144.

7. Bosse $\mathrm{Y}$, Hudson TJ: Toward a comprehensive set of asthma susceptibility genes. Annu Rev Med 2007; 58:171-184.

8. Damera, G. and R.A. Panettieri Jr., 2011. Does airway smooth muscle express an inflammatory phenotype in asthma? Br. J. Pharmacol., 163: 68-80.

9. Damera, G. and R.A. Panettieri Jr., 2011. Does airway smooth muscle express an inflammatory phenotype in asthma? Br. J. Pharmacol., 163: 68-80.

10. Krouse, J. H., Brown, R. W., Fineman, S. M., Han, J. K., Heller, A. J., Joe, S., \& Veling, M. C. Asthma and the unified airway. Otolaryngology-Head and Neck Surgery. 2007; 136 (5):S75-S106.

11. Correale J, Ysrraelit MC, Gaitan MI. Immunomodulatory effects of Vitamin D in multiple sclerosis. Brain. 2009 May; 132 (Pt 5):1146-60.

12. Correale J, Ysrraelit MC, Gaitan MI. Immunomodulatory effects of Vitamin D in multiple sclerosis. Brain. 2009 May; 132 (Pt 5):1146-60.
13. Lisa Biggs, Chunping Yu,Boris Fedoric, Angel F. Lopez, Stephen J. Galli, and Michele A. Grimbaldestonevidence that vitamin $D_{3}$ promotes mast cell-dependent reduction of chronic UVBinduced skin pathology in mice. J Exp Med. 2010 Mar 15; 207(3): 455-463.

14. Adams JS, Hewison M Update in Vitamin D. J Clin Endocrinol Metab. 2010; 95: 471-478.

15. Johansson SG. Raised levels of a new immunoglobulin class (IgND) in asthma. The Lancet. $1967 \mathrm{Nov}$ 4;290(7523):951-3.

16. Zetterstöm $\mathrm{O}$, Johansson SG. IgE concentrations measured by PRIST ${ }^{\circledR}$ in serum of healthy adults and in patients with respiratory allergy: a diagnostic approach. Allergy. 1981 Nov;36(8):537-47.

17. Ambjørn J, Loll R, Westra W, Zohren S. Putting a cap on causality violations in causal dynamical triangulations. Journal of High Energy Physics. 2007 Dec 4;2007(12):017.

18. Ambjørn J, Loll R, Westra W, Zohren S. Putting a cap on causality violations in causal dynamical triangulations. Journal of High Energy Physics. 2007 Dec 4;2007(12):017.

19. Croner S, Kjellman NI, Eriksson B, Roth A. IgE screening in 1701 newborn infants and the development of atopic disease during infancy. Archives of disease in childhood. 1982 May 1;57(5):364-8.

20. Michel FB, Bousquet J, Greillier P, RobinetLevy M, Coulomb Y. Comparison of cord blood immunoglobulin $E$ concentrations and maternal allergy for the prediction of atopic diseases in infancy. Journal of Allergy and Clinical Immunology. 1980 Jun 1;65(6):422-30.

21. Tietz, N.W. ed., Clinical guide to laboratory tests, 3rd Edition, W.B. Saunders, Co., Philadelphia, 1995:358.

22. Holick MF. Vitamin D deficiency. N Engl J Med. 2007; 357: 266-281.

23. Tonegawa S. Somatic generation of antibody diversity. Nature. 1983; 302:575-581.

24. Litonjua AA, Hollis BW, Schuemann BK, Celedón JC, Fuhlbrigge AL, Raby BA, Weiss ST. Low serum vitamin D levels are associated with increased asthma exacerbations among children using regular inhaled corticosteroids. J Allergy Clin Immunol. 2008; 121:S144. 
25. Svedahl S, Svendsen K, Qvenild T, Sjaastad AK, Hilt $B$. Short term exposure to cooking fumes and pulmonary function. Journal of Occupational Medicine and Toxicology. 2009 Dec 1;4(1):9.

26. Albano, G. D., Di Sano, C., Bonanno, A., Riccobono, L., Gagliardo, R., Chanez, P.,\& Profita, M. Th17 immunity in children with allergic asthma and rhinitis: A pharmacological approach. PloS one. 2013; 8(4):e58892.

27. Ginde AA, Mansbach JM, Camargo CAJr. Association between serum 25-hydroxyvitamin $D$ level and upper respiratory tract infection in the Third National Health and Nutrition Examination Survey. Arch Intern Med. 2009; 169:384-90.

28. Martin TR, Takeishi T, Katz HR, Austen KF, Drazen JM \& Galli SJ. Mast cell activation enhances airway responsiveness to methacholine in the mouse. Journal of Clinical Investigation.1993; 91:1176-1182.
30. Anupama N, Vishnu Sharma M, Nagaraja HS. 2005. Ramesh BhatThe serum immunoglobulin E level reflects the severity of bronchial asthma. American review of respiratory disease. 2005; 18 (3):35-40.

31. Litonjua, A. A., \& Weiss, S. T. Is vitamin D deficiency to blame for the asthma epidemic. Journal of Allergy and Clinical Immunology. 2007; 120(5):1031-1035.

32. Anupama N, Vishnu Sharma M, Nagaraja HS. 2005. Ramesh BhatThe serum immunoglobulin E level reflects the severity of bronchial asthma. American review of respiratory disease. 2005; 18 (3):35-40.

33. Holick MF. Vitamin D deficiency. N Engl J Med. 2007; 357: 266-281.

\begin{tabular}{|c|c|c|c|}
\hline \multicolumn{4}{|c|}{ AUTHORSHIP AND CONTRIBUTION DECLARATION } \\
\hline Sr. \# & Author(s) Full Name & Contribution to the paper & Author(s) Signature \\
\hline 1 & Hira Liaquat & $\begin{array}{l}\text { Main investigator \& drafting of } \\
\text { work. }\end{array}$ & \\
\hline 2 & Syed Adnan Ahmed & $\begin{array}{l}\text { Conception and Drafting the } \\
\text { work and revising it critically for } \\
\text { important intellectual content. } \\
\text { Drafting \& technical facilitation. }\end{array}$ & \\
\hline 4 & Tayyaba Kazmi & Drafting \& technical facilitation. & \\
\hline 5 & Amar Lal Dodani & Lab technical facilitation. & \\
\hline 6 & Ruqaya & Drafting \& Statistical Analysis. & \\
\hline
\end{tabular}

